\title{
EVALUATION ON MECHANICAL FRACTURE OF PWR PRESSURE VESSEL AND MODELING BASED ON NEURAL NETWORK
}

\author{
Mike Susmikanti, Roziq Himawan, Abdul Hafid, Entin Hartini \\ Center for Nuclear Reactor Technology and Safety, National Nuclear Energy Agency of Indonesia \\ Puspiptek Area,Tangerang, 15310 Indonesia \\ E-mail: mike@batan.go.id \\ Diterima editor: 3 April 2016 \\ Diperbaiki: 16 Juni 2016 \\ Disetujui untuk publikasi: 22 Juni 2016
}

\begin{abstract}
EVALUATION ON MECHANICAL FRACTURE OF PWR PRESSURE VESSEL AND MODELING BASED ON NEURAL NETWORK. The important component of the PWR is a pressure vessel. The material resistance in the pressure vessel needs to be evaluated. One way of evaluation is by the mechanical fracture analysis. The modeling needs to know the phenomena of the analysis result in general. A number of researches have been completed on the calculation of mechanical fracture in the pressure vessel with an internal load. The mechanical fracture was modeled using a neural network approach. In relation to the material resistance of the pressure vessel, which is used in PWR AP1000, the material must be evaluated because of the effect of the load. The modeling is needed to predict the effect of the load. The aim of this study is to evaluate the material resistance through mechanical fracture analysis because of the influence load on the pressure vessel on PWR AP1000. The material, which was observed, is SA 508. This analysis consists of the calculation of stress intensity factor and J-integral with some load at the crack propagation position. The fracture mechanic was analyzed by finite element simulation. The result of Stress Intensity factor and J-Integral was compared with fracture toughness to know the durability of the material. The modeling of J-Integral and Stress Intensity Factor were obtained for some load based on neural network approach.
\end{abstract}

Keywords: Material resistance, mechanical fracture, neural network, PWR, pressure vessel, crack propagation.

\begin{abstract}
ABSTRAK
EVALUASI FRAKTUR MEKANIK PADA BEJANA TEKAN PWR DAN PEMODELAN BERBASIS NEURAL NETWORK. Komponen penting dari PWR adalah bejana tekan. Ketahanan bahan di bejana tekan perlu dievaluasi. Salah satu cara adalah dengan analisis fraktur mekanik. Pemodelan diperlukan untuk mengetahui fenomena hasil analisis pada umumnya. Terdapat penelitian untuk perhitungan fraktur mekanik dalam bejana tekan dengan beban internal. Penelitian lain adalah hasil dari fraktur mekanik dimodelkan menggunakan pendekatan jaringan syaraf. Sehubungan dengan ketahanan material dari bejana tekan yang digunakan dalam PWR AP1000, bahan harus dievaluasi karena efek dari beban. Pemodelan diperlukan untuk memprediksi pengaruh beban pada bahan dalam bejana tekan. Tujuan dari penelitian ini adalah untuk mengevaluasi ketahanan material melalui analisis fraktur mekanik karena pengaruh beban pada bejana tekan. Bahan yang diamati, adalah SA 508. Analisis ini terdiri dari perhitungan faktor intensitas tegangan dan J-integral dengan beberapa beban pada posisi perambatan retak. Fraktur mekanik dianalisis dengan metode elemen hingga. Hasil faktor intensitas tegangan dan JIntegral dibandingkan dengan ketangguhan patah untuk mengetahui daya tahan material. Pemodelan JIntegral dan faktor intensitas stres diperoleh untuk beberapa beban berdasarkan jaringan saraf.
\end{abstract}

Kata kunci: Ketahanan bahan, teknik patahan, jaringan syaraf, PWR, bejana tekan, perambatan retak. 


\section{INTRODUCTION}

The study of the operating life time of a reactor is very important for ageing management. Regarding ageing process, it is necessary to really concern for the most important components of a reactor. One of the important component is the pressure vessel. Overload can cause cracking on the wall of the pressure vessel. The limit of maximum load needs to be evaluated for preventing cracking of material which uses on the wall of the pressure vessel. The researches on the mechanical fracture for material resistance have been widely performed. Therefore, the modeling is needed to describe the limit of maximum load for the condition of a material resistance.

Analysis on the mechanical fracture using the Stress Intensity Factor (SIF) especially on a crack of the plate has been performed [1]. The similar research has also been performed for predicting fracture toughness of specimens with the load [2]. The SIF for modes-I uses the finite element method has been calculated [3]. The probabilistic of mechanical fracture was investigated on a piping of a nuclear power plant [4]. Probabilistic of fracture mechanic on hot piping was analyzed especially in aging PWR [5]. In the same way, the reactor safety were also analyzed with the probabilistic of fracture mechanics [6]. The other research on mechanical fracture analysis of pressure vessel was analyzed for the brittle steel SA-508 CL 3 in the pressure vessel of the reactor [7]. The analysis of the fracture mechanics for SA 508 GR 1A material has been done on piping NPP using Compact Tension (CT) and a large specimen [8]. The calculation of SIF was analyzed in the pressure vessels with internal load [9]. The calculation of SIF was done using semi-analytic in Finite Element Analysis (FEA). The modeling of SIF for the crack propagation was done use neural network [10]. Finally, the analysis of fracture is one prospect for failure analysis [11].

The mechanical fracture has not yet analyzed for the material of SA 508 which is used in the pressure vessel of AP1000. The calculation of the J-integral and the SIF have not been done on some load and some position of a crack propagation. The modeling is needed to predict the maximum limit which is allowable for the condition of material resistance. The purpose of the present study is to evaluate the material resistance, especially the material SA 508, which is used in the wall of the pressure vessel of PWR AP1000. The mechanical fracture of SA 508 was analyzed by finite element method using MSC-MARC software. The release value of the energy rate (JIntegral) was calculated on some load and the position of crack initial. After then, the SIF value was calculated from the J-Integral value. The value of SIF was compared to the standard values of the fracture toughness of the same material. The modeling of the SIF and the J-Integral are simulated based on neural network approach using MATLAB software.

Meanwhile, the load limit for SA 508 which use in the pressure vessel PWR AP1000 was analyzed by using the mechanical fracture. The value of the J-integral and the SIF are obtained at some position of the initial crack with some load. The modeling based on a neural network has been done for the J-Integral and the SIF in relation to the durability of SA 508. This modeling was done by focusing on some loads and some positions of initial crack which are given. By considering, the value of SIF with the value of fracture toughness, then the maximum limit of the load can be known to avoid the crack in the structure of the component.

\section{THEORY}

Fracture mechanic is one way to determine the propagation of cracks in the structure of material. Figure 1 shows the model of the crack (Mode I) in the form of three-dimensional (3-D) [3]. While early models in the form of two-dimensional crack are shown in Figure 2. 


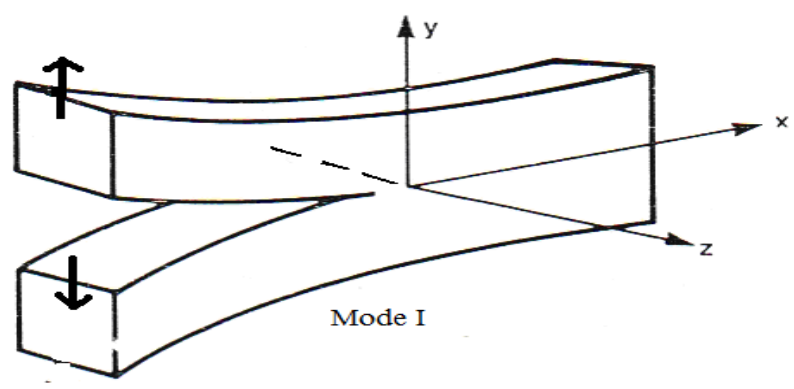

Figure 1. The initial crack model in 3-D [3].

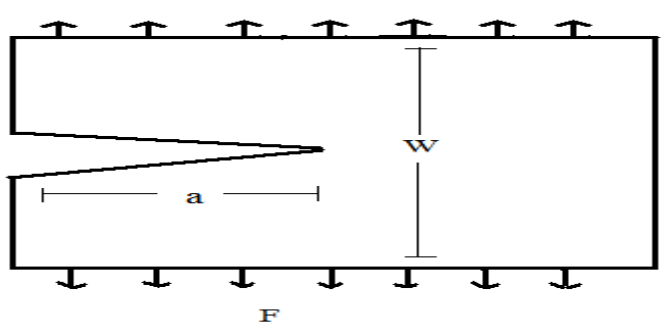

Figure 2. The initial crack model in 2-D [3].

The fracture toughness of material is the material ability to resist the propagation of cracks due to the load that works with attention on material defects, the geometry of the material, loading conditions and the nature of the material used. The value of the fracture toughness is the ability value of the component to resist crack propagation. The value of fracture toughness is influenced by the thickness of a material. This value tends to a constant if exceed a load limit. The fracture toughness has a different value depending on temperature conditions. Toughness properties of materials in curbing cracks are expressed as the toughness of the material $\left(K_{I}\right)$. The parameter of Stress Intensity Factor $\left(K_{I C}\right)$ is used to predict the rate of crack-related fatigue life prediction. The resistance cracking was evaluated by comparing the value of $K_{I}$ and $K_{I C}$. If the value $K_{I}$ is smaller than $K_{I C}$, then the construction material is still safe. Conversely, if the value $K_{I}$ approaches the values $K_{I C}$, it can be said that the construction material can be failed.

The rate of release energy nonlinear expressed as an integral line called J-integral. The value of J-Integral was evaluated around the contour of crack. The J-integral can be modified numerically using the integral line or the integral path which expressed in equation 1 [3].

$$
J_{p}=\int_{r}(W d y-T \partial u / \partial x) d r
$$

where $r$ is the integral path which containing the crack tip, $T$ is the surface tension vector, $u$ is the vector of movement in $d r$. Differentiation path contour, $x, y, z$ are the rectangular coordinate system, $W$ is the strain energy density. J-integral is expressed by equation 2 [12],

$$
J=\left(K_{I C}^{2} / \sigma^{2}\right)\left(\left(1-v^{2}\right) / E\right)
$$

where $K_{I C}$ is fracture toughness, $\sigma$ is a load, $E$ is the Young's modulus, $v$ is the value of Poison ratio, $J$ is the value of the J-Integral.

In Linear Elastic Fracture Mechanics (LEFM), the age of the crack growth is identified by a parameter called the Stress Intensity Factor $\left(K_{I}\right) \cdot K_{I}$ is a function of the crack length $a$ and the working stress $\sigma$ but varies with the type of the fracture and the load. The Stress Intensity Factor is expressed by equation 3 [3],

$$
K_{I}=\sigma \sqrt{\pi a} \cdot f(a / W)
$$


which $\sigma$ is the nominal stress, $a$ is the crack length, $W$ is the width of the specimen and $f(a / W)$ is a function of the crack length to the width of the specimen.

The fracture occurs when the fracture toughness of material $K_{I C}$ is reached, that means $K_{I}=K_{I C}$. The Stress Intensity Factor can also be expressed by equation 4 [1].

$$
K_{I}=\sqrt{\frac{E}{1-v^{2}} J_{I}}
$$

where $J_{I}$ is the J-Integral

\section{METHODOLOGY}

In the first study, the mechanical fracture analysis uses the two-dimensional plate. The next study the mechanical fracture analysis will use three-dimensional plate for comparing the level of accuracy of the two-dimensional plate.

In this study, the first geometry properties are defined for input. Next, the geometry of plate is created with some mesh in the program pre-processor using the MSC MARC. The input of sample geometry is a length and a width of the plate. The geometric properties are the Poisson ratio, the young's modulus and a range of the load. The position of initial crack is given on the edge of the geometry. The boundaries condition is given for the geometry of the plate. The output is the J-Integral value by doing job run, submit and display necessary options. This case includes the J-integral, displacement Von Misses Stress, Contour-Band, and Contour-Line. After the Jintegral is obtained, the value of SIF can be calculated. The result of SIF is compared with the value of fracture toughness. The fracture toughness value is based on references or standard of material which recommended, based on the material used for given the load and the boundary condition.

The result of the J-Integral and SIF, which are used for modeling are based on the neural network. The modeling uses function facilities in the MATLAB. There are some aspects of the information, which are needed for decision making, such as the topology of the neural network. This topology consists of input and output variables, the number of neuron in each layer, the type of the neuron function in each layer, the biased value with learning function and training function. The model of the neural network is shown in Figure 3 [10].

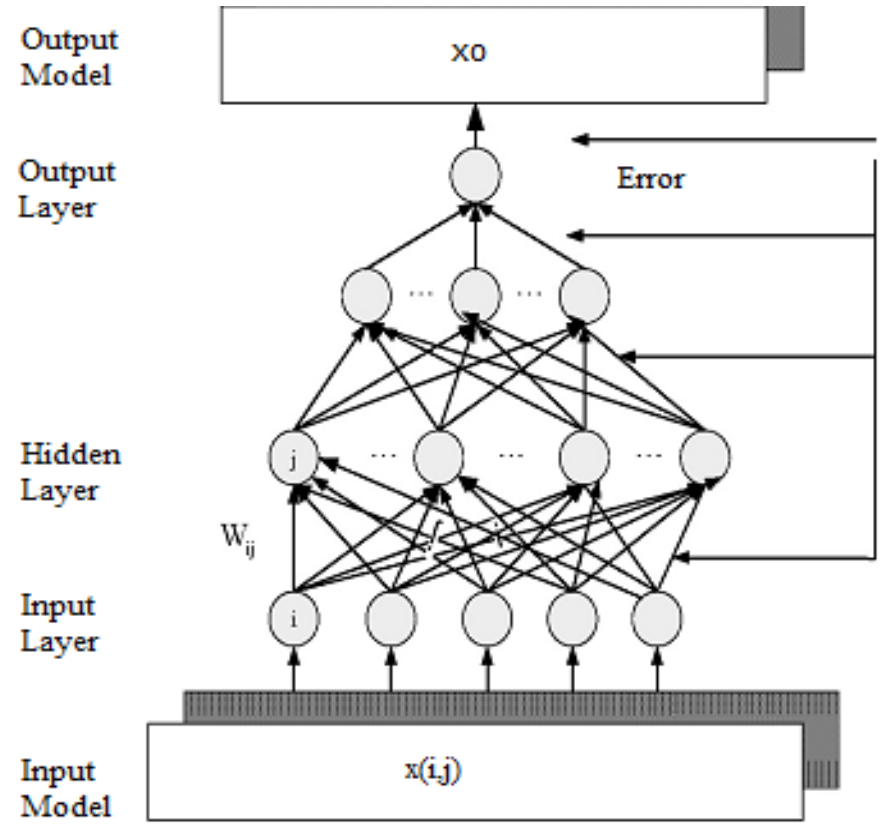

Figure 3. The model of Neural Network [10]. 
The algorithm of the neural network is shown in Figure 4 [10]. Firstly, the input information which is needed are collected. The number of the output layer and hidden layer are prepared. The next, the input data was normalized. The output of hidden neurons was simulated with the output neurons. The average square root is calculated for the output error. If the error is still greater than or equal to the value of error tolerance, the calculation is continued by giving appropriate weight between the hidden layer and the output layer. The backpropagation is calculated for the hidden layer and output layer. If the error is smaller than the error tolerance, then the training of neural network continuously uses the factor value appropriate until compatible with the output which is expected.

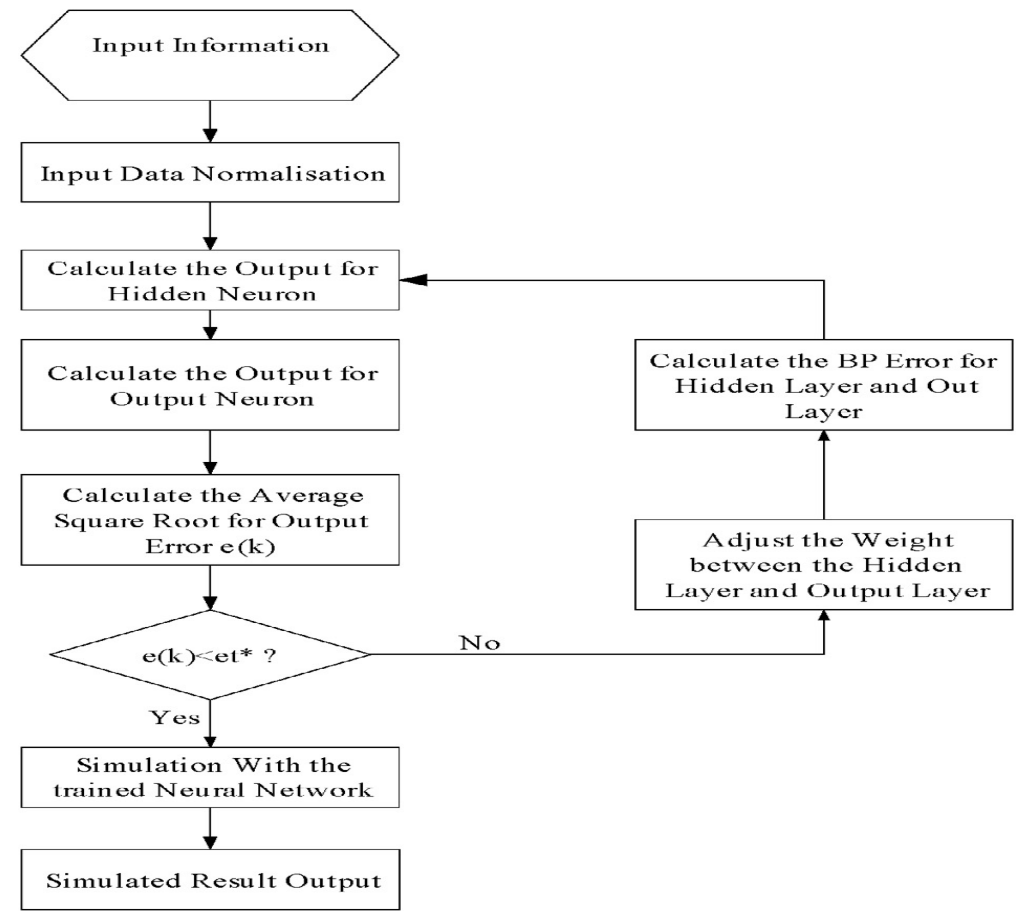

Figure 4. The Algorithm of Neural Network [10].

\section{RESULTS AND DISCUSSION}

The sample is a plate which is used in the wall of a pressure vessel of AP1000. The type of material is SA 508. The sample geometry has a length $600 \mathrm{~mm}$ and a width $500 \mathrm{~mm}$ [13]. The ratio poison (v) for this material is 0.3 and young's modulus (E) is $187 \times 10^{3} \mathrm{MPa}$ [5]. The load is given between 50 to $115 \mathrm{MPa}$, based on the assumption that the pressure of the AP1000 PWR in operating condition is $15.95 \mathrm{MPa}$ and the design is $17.1 \mathrm{MPa}$ [14]. The load is given the same as with the operating condition. The fracture toughness for material SA 508 from experimental is in range 25 to $100 \mathrm{MPa}$ [13]. In this simulation, the stress of material will analyze in the wall of a pressure vessel. The initial crack position from the edge of the plate was simulated in range $50 \mathrm{~mm}$ to $200 \mathrm{~mm}$. The geometry plate is shown in Figure 5. 


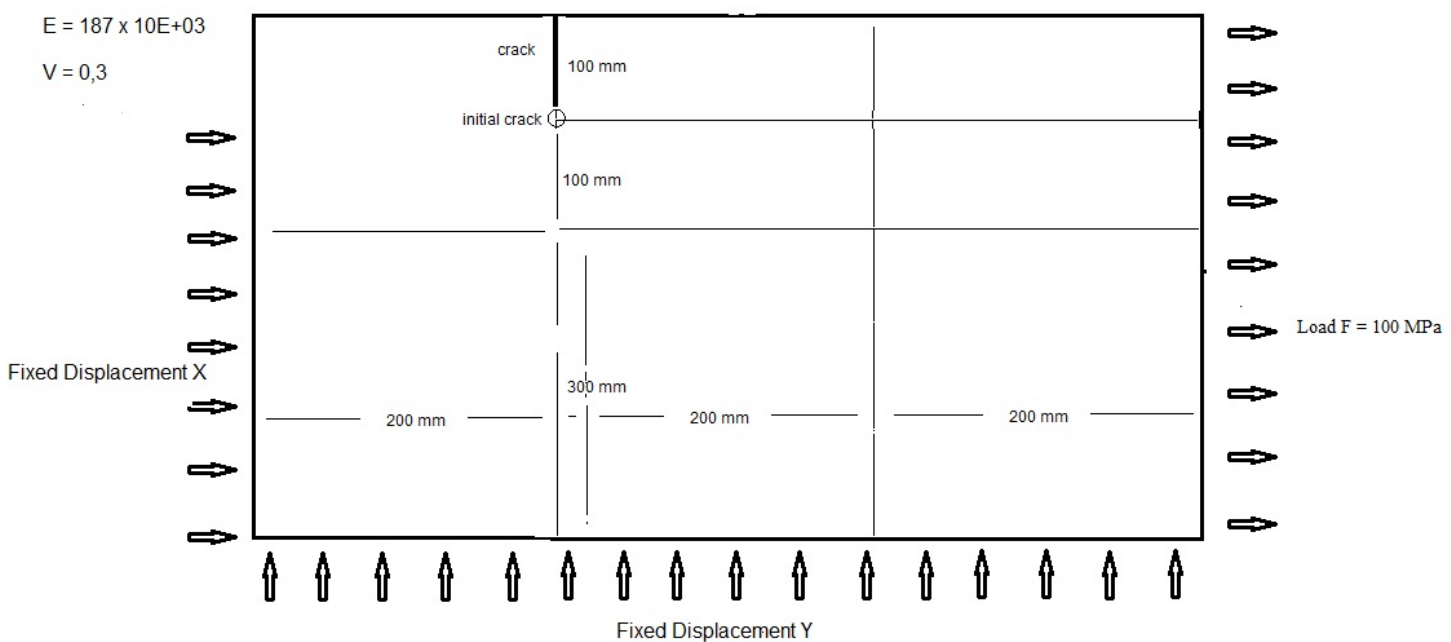

Figure 5. Sample Geometry Plate SA 508.

The SA 508 steel is a basic material which is used in the wall of AP1000 pressure vessel. The chemical composition of material SA 508 is presented in Table 1 [7].

Table 1. Composition of chemical elements in steel SA 508 [7].

\begin{tabular}{ccccccccccc}
\hline Element & $\mathrm{C}$ & $\mathrm{Si}$ & $\mathrm{Mn}$ & $\mathrm{P}$ & $\mathrm{S}$ & $\mathrm{Ni}$ & $\mathrm{Cr}$ & $\mathrm{Mo}$ & $\mathrm{Al}$ & $\mathrm{Cu}$ \\
\hline $\begin{array}{c}\text { Weight } \\
(\%)\end{array}$ & 0.21 & 0.27 & 0.69 & 0.005 & 0.004 & 0.78 & 0.38 & 0.63 & 0.015 & 0.16 \\
\hline
\end{tabular}

The J-integral was calculated with the finite element method use MSC MARC software. The load factor is given in range $50 \mathrm{MPa}$ to $115 \mathrm{MPa}$. The initial crack position was given in range 50 $\mathrm{mm}$ to $200 \mathrm{~mm}$. The calculation of J-Integral is described in Table 2 .

Table 2.The result of J-integral calculation.

\begin{tabular}{cccccccc}
\hline & \multicolumn{7}{c}{$\begin{array}{c}\text { Initial Crack } \\
(\mathrm{mm})\end{array}$} \\
\hline Load (MPa) & 50 & 75 & 100 & 125 & 150 & 175 & 200 \\
\hline 50 & 0.0027 & 0.0042 & 0.0056 & 0.0082 & 0.0111 & 0.0144 & 0.0191 \\
75 & 0.0061 & 0.0094 & 0.0126 & 0.0184 & 0.0251 & 0.0324 & 0.0429 \\
80 & 0.0069 & 0.0107 & 0.0144 & 0.0209 & 0.0285 & 0.0369 & 0.0487 \\
85 & 0.0078 & 0.0121 & 0.0162 & 0.0236 & 0.0322 & 0.0414 & 0.0552 \\
90 & 0.0087 & 0.0135 & 0.0182 & 0.0265 & 0.0361 & 0.0467 & 0.0618 \\
95 & 0.0097 & 0.0151 & 0.0202 & 0.0295 & 0.0408 & 0.0520 & 0.0689 \\
100 & 0.0108 & 0.0169 & 0.0224 & 0.0326 & 0.0445 & 0.0576 & 0.0764 \\
105 & 0.0119 & 0.0184 & 0.0247 & 0.0360 & 0.0491 & 0.0636 & 0.0842 \\
110 & 0.0130 & 0.0202 & 0.0271 & 0.0395 & 0.0539 & 0.0697 & 0.0924 \\
115 & 0.0142 & 0.0221 & 0.0296 & 0.0432 & 0.0589 & 0.0762 & 0.1010 \\
\hline
\end{tabular}

The result of J-integral is obtained by a factor of load and crack initial position which is given in Table 2. The calculation result of the SIF (Tabel 3) is obtained from the result of J-integral in Table 2 according to the equation (4). For example, at load $100 \mathrm{MPa}$ and the position of initial crack $100 \mathrm{~mm}$ from Table 2, the J-integral is obtained 0.0224 .

From the analytical calculation, for example, the fracture toughness $K_{I C}$ is $95 \mathrm{MPa}$. Then Jintegral value is $J=\left(K_{I C}^{2}\right)\left(\left(1-v^{2}\right) / E\right)=\left(95^{2}\right)\left(\left(1-0.3^{2}\right) / 187000\right)=0.0439$. The J-integral result from the simulation is 0.0445 . The difference between analytic calculation and simulation is 
$(0.0445-0.0439) / 0.0445 \times 100 \%=0.0006 / 0.0445 \times 100 \%=1.37 \%$. It means, there are not a significant difference because statistically the significant values, in general, is about 5\%. Thus, the J-Integral value with analytic and simulation with software MSC MARC does not have a significant difference.

From J-integral calculation in Table 2, the value of SIF calculation is follows,

$$
K_{I}=\sqrt{\frac{E}{1-v^{2}} J}=\sqrt{\frac{187000}{1-0.3^{2}} J}=\sqrt{\frac{187000}{0.91} J}=453.31 \sqrt{J}
$$

For the J-integral value 0.0224 then the SIF value is $K_{I}=453.31 \sqrt{0.0224}=453.31(0.1497)=$ 67.8460 MPa $\sqrt{m}$ and so on as shown in Table 3.

Table 3. The results of Stress Intensity Factor calculation $(\mathrm{MPa} \sqrt{m})$

\begin{tabular}{cccccccc}
\hline \multicolumn{7}{c}{$\begin{array}{c}\text { InitialCrack } \\
(\mathrm{mm})\end{array}$} \\
\hline $\begin{array}{c}\text { Beban } \\
(\mathrm{MPa})\end{array}$ & 50 & 75 & 100 & 125 & 150 & 175 & 200 \\
\hline 50 & 23.5546 & 29.3778 & 33.9226 & 41.0489 & 47.7591 & 54.3972 & 62.6486 \\
75 & 35.2742 & 43.9154 & 50.8845 & 61.4371 & 71.8186 & 81.6118 & 93.9511 \\
80 & 37.6251 & 46.8430 & 54.3978 & 65.5334 & 76.5284 & 87.0530 & 100.0605 \\
85 & 39.9766 & 49.7718 & 57.6976 & 69.6292 & 81.3445 & 92.1936 & 106.4779 \\
90 & 42.3286 & 52.6997 & 61.1555 & 73.7261 & 86.1299 & 97.9349 & 112.7416 \\
95 & 44.6786 & 55.6268 & 64.4282 & 77.8211 & 91.5651 & 103.3757 & 119.0053 \\
100 & 47.0247 & 58.5549 & 67.8460 & 81.9172 & 95.6269 & 108.8164 & 125.2684 \\
105 & 49.3822 & 61.4823 & 71.2440 & 86.0129 & 100.4479 & 114.3037 & 131.5317 \\
110 & 51.7336 & 64.4106 & 74.6251 & 90.1083 & 105.2433 & 119.6983 & 137.7951 \\
115 & 54.0853 & 67.3383 & 77.9913 & 94.2045 & 110.0165 & 125.1388 & 144.0593 \\
\hline
\end{tabular}

Suppose the J-Integral in Table 3 were obtained for a load $100 \mathrm{MPa}$ and an initial crack 100 $\mathrm{mm}$ from the edge plate is 0.0224 . In the experiment, the fracture toughness of material SA 508 is recommended within 25 to $100 \mathrm{MPa} \sqrt{m}$ [8]. The SIF $\mathrm{K}_{\mathrm{I}}$ is still less than $\mathrm{K}_{\mathrm{IC}}$. These means a material is still within safe limit from cracking for a given load $100 \mathrm{MPa}$ and an initial crack position $100 \mathrm{~mm}$.

In the calculation results of a load $100 \mathrm{MPa}$ and an initial crack $175 \mathrm{~mm}$ from the plate edge, the J-integral is obtained 0.0575. Then the SIF is $108.8164 \mathrm{MPa}$. The SIF is greater than fracture toughness $\left(\mathrm{K}_{\mathrm{I}}>K_{I C}\right)$. The fracture toughness maximum is $100 \mathrm{MPa}$ [8]. Similarly, for the initial load of $105 \mathrm{MPa}$ and position of initial crack $150 \mathrm{~mm}$ from the plate edge, the J-integral is obtained 0.0495. The SIF is obtained 100.4479 MPa. The SIF is greater than fracture toughness $\left(\mathrm{K}_{\mathrm{I}}>K_{I C}\right)$. It means the material is not in the safe limits condition of cracking. The given load $100 \mathrm{MPa}$, the position of initial crack must less than $150 \mathrm{~mm}$.

The analysis result of the J-integral 0.02242 (2.242e-002) shown in Figure 6, for given load is $100 \mathrm{MPa}$ and the position of initial crack is $100 \mathrm{~mm}$. This value is in yellow box image. The trend of J-integral is shown in the blue to the yellow contour-band. The blue one is shown the value of J-integral minimum in $0.002242(2.242 \mathrm{e}-003)$. The yellow one is shown the value of J-integral maximum 0.02242 (2.242e-02). The value of J-integral is increasingly from $0.00224,0.00448$ until 0.0224 , for the blue box until the yellow box. The blue box showed that the material is still more safety, but in the yellow box, start to be careful. 


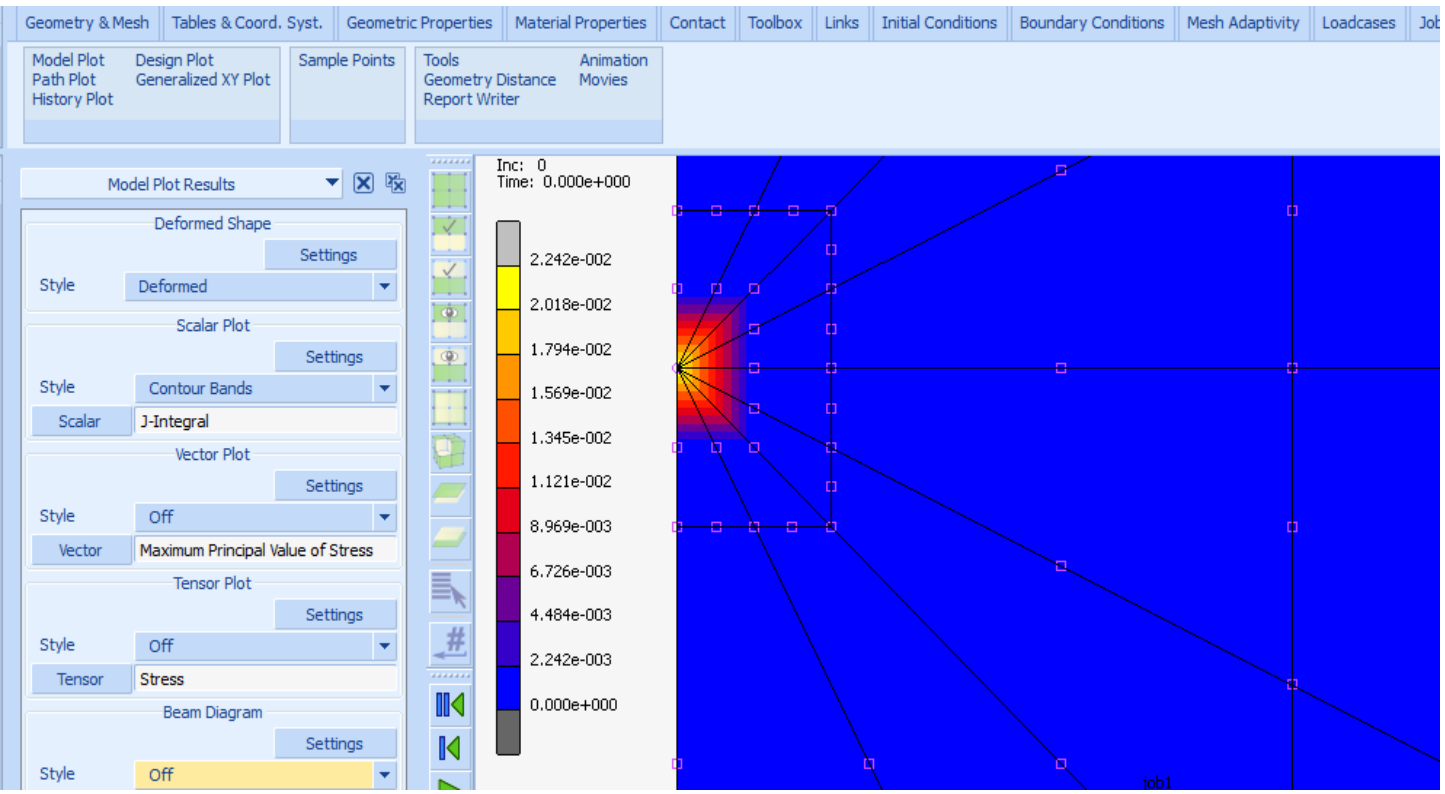

Figure 6. The J-integral value at load $100 \mathrm{M} \mathrm{Pa}$ and initial crack $100 \mathrm{~mm}$ in contour band

The result of the J-integral for load $100 \mathrm{MPa}$ and initial crack $100 \mathrm{~mm}$ are shown in Figure 7, with a contour line option. The contour line of J-integral shown that the minimal value is 0.002491 (2.491e-03) and the maximal value is $0.02242(2.242 \mathrm{e}-02)$. The load is $100 \mathrm{MPa}$ still safety in the position of initial crack $100 \mathrm{~mm}$.

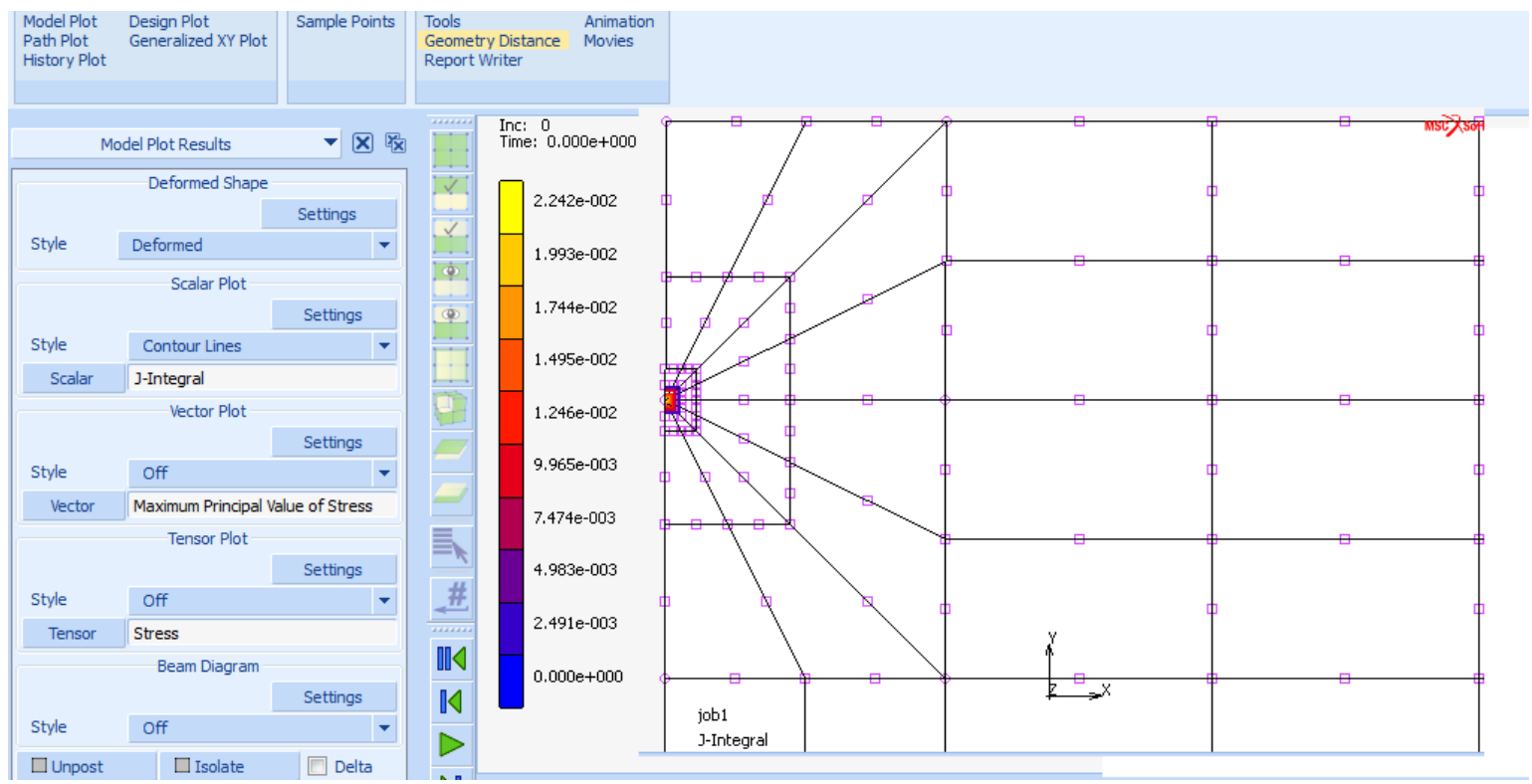

Figure 7. The contour band of J-integral at load $100 \mathrm{MPa}$ and initial crack position $100 \mathrm{~mm}$.

The result of the J-integral shown in Figure 8 with deformation option. It appears that there is a deformation if given a load of $100 \mathrm{MPa}$ and an initial crack $100 \mathrm{~mm}$. 


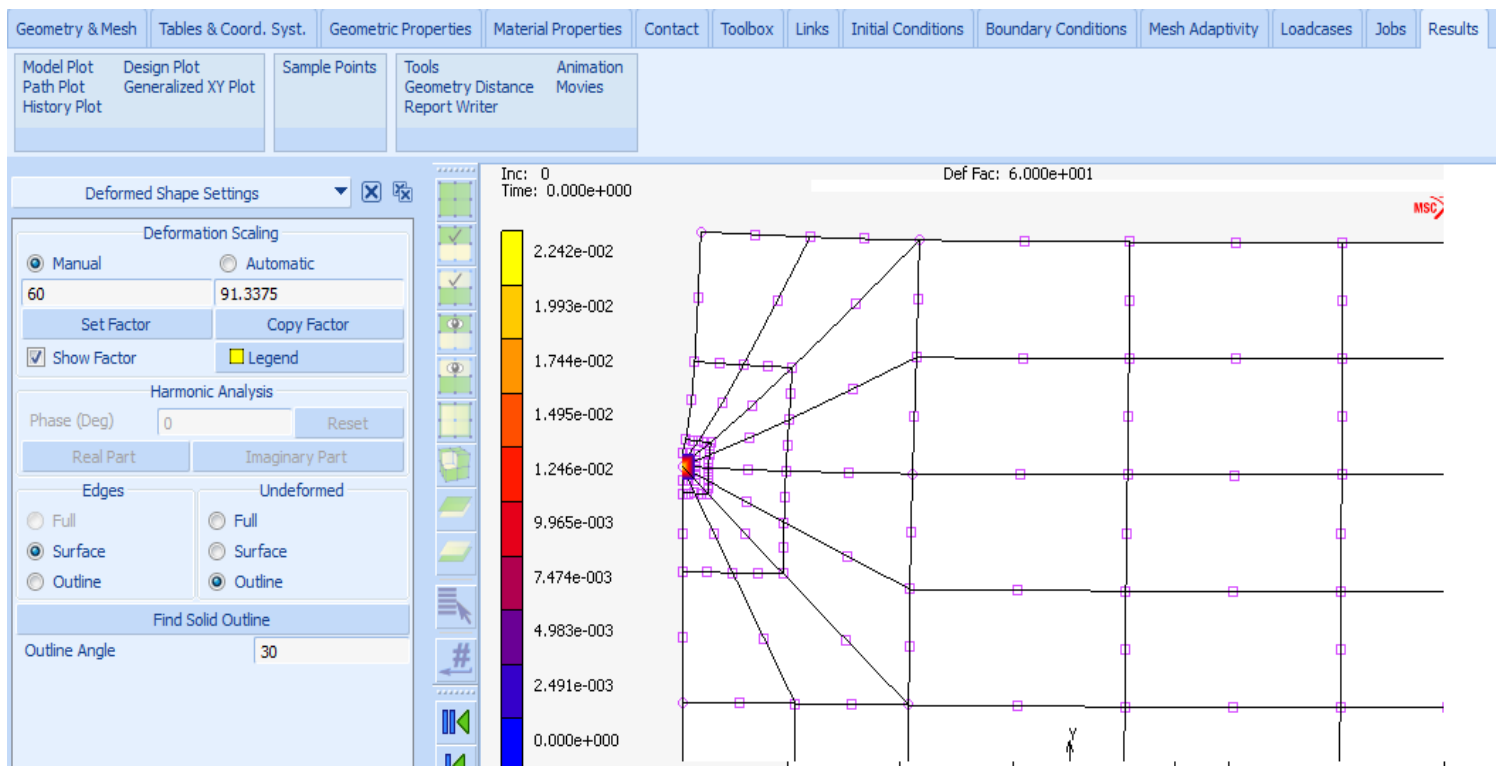

Figure 8. The result of the J-integral with a deformation option

The plot of the J-integral in a neural network using MATLAB with the load given respectively in range 50 to $115 \mathrm{MPa}$ and the position of an initial crack in range 50 to $200 \mathrm{~mm}$ are shown in Figure 9.

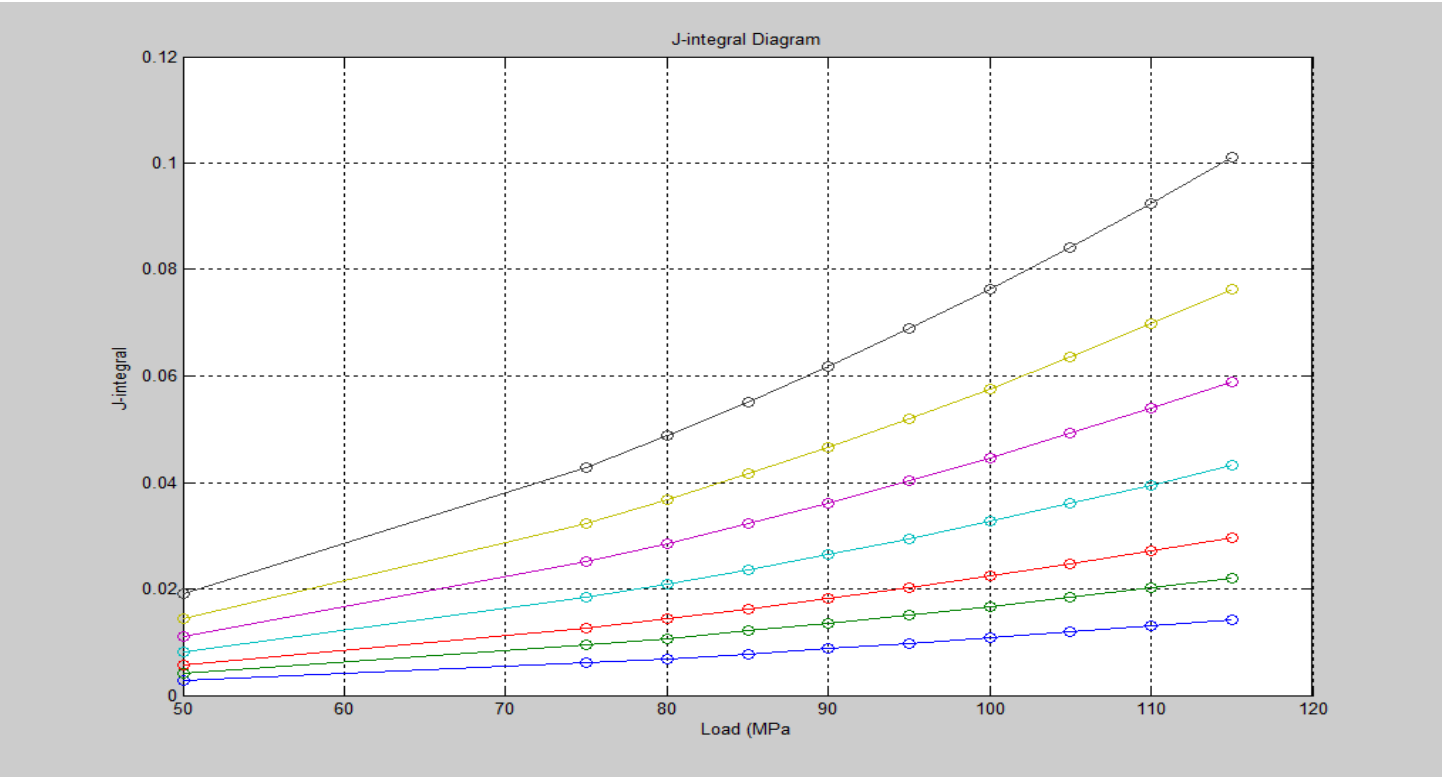

Figure 9. Plot of the J-Integral

The modeling of J-Integral based on the neural network shown in Figure 10. This model is a result of training data of the load and the initial crack position. The curve fitting from the bottom to the top are initial crack position at $50 \mathrm{~mm}, 75 \mathrm{~mm}, 100 \mathrm{~mm}, 125 \mathrm{~mm}, 150 \mathrm{~mm}, 175 \mathrm{~mm}$ and 200 $\mathrm{mm}$ 


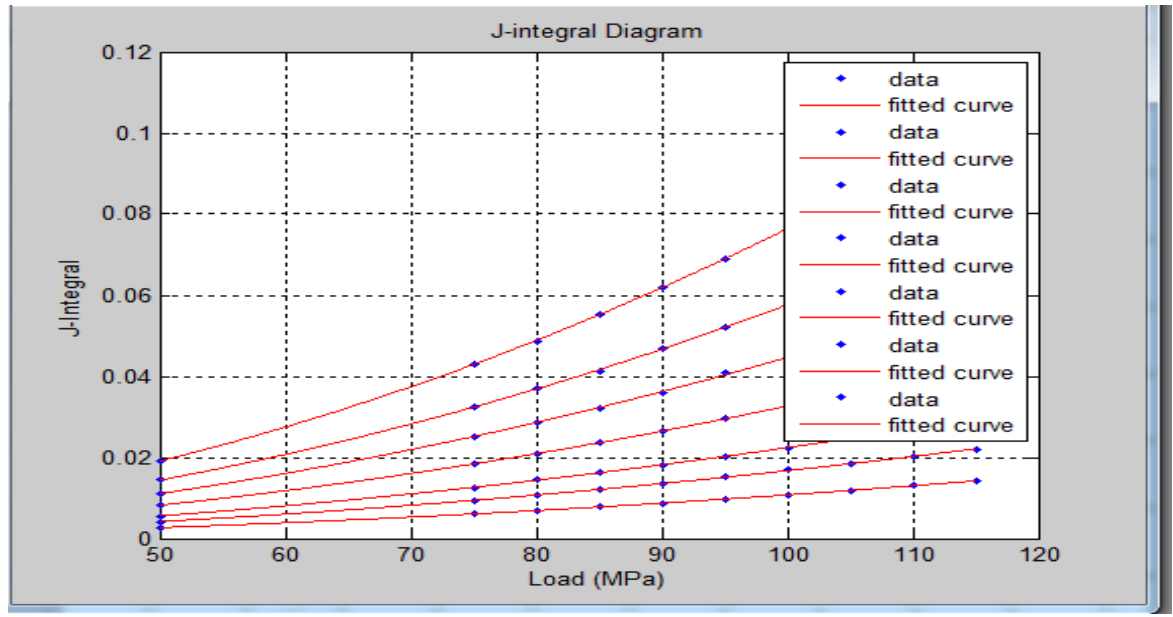

Figure 10. The modeling of J-Integral based on neural network

The plot of the Stress Intensity Factor for load in range 50 to $115 \mathrm{MPa}$ and the initial crack position respectively $50 \mathrm{~mm}, 75 \mathrm{~mm}, 100 \mathrm{~mm}, 125 \mathrm{~mm}, 150 \mathrm{~mm}, 175 \mathrm{~mm}$ and $200 \mathrm{~mm}$ from Table 3, shown in Figure 11.

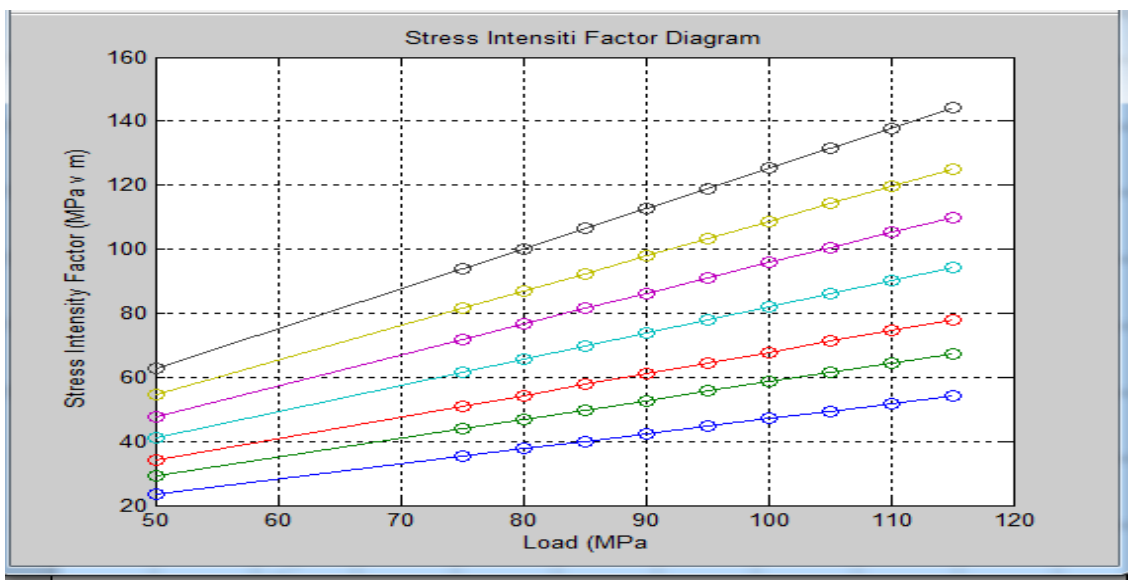

Figure 11. Plot of the Stress Intensity Factor

The modeling of stress intensity factor or curve fitting based on the neural network for a given load between 50 to $115 \mathrm{MPa}$ and the initial crack position at $75 \mathrm{~mm}, 100 \mathrm{~mm}, 125 \mathrm{~mm}, 150$ $\mathrm{mm}, 175 \mathrm{~mm}$ and $200 \mathrm{~mm}$ from the edge of the plate shown in Figure 12.

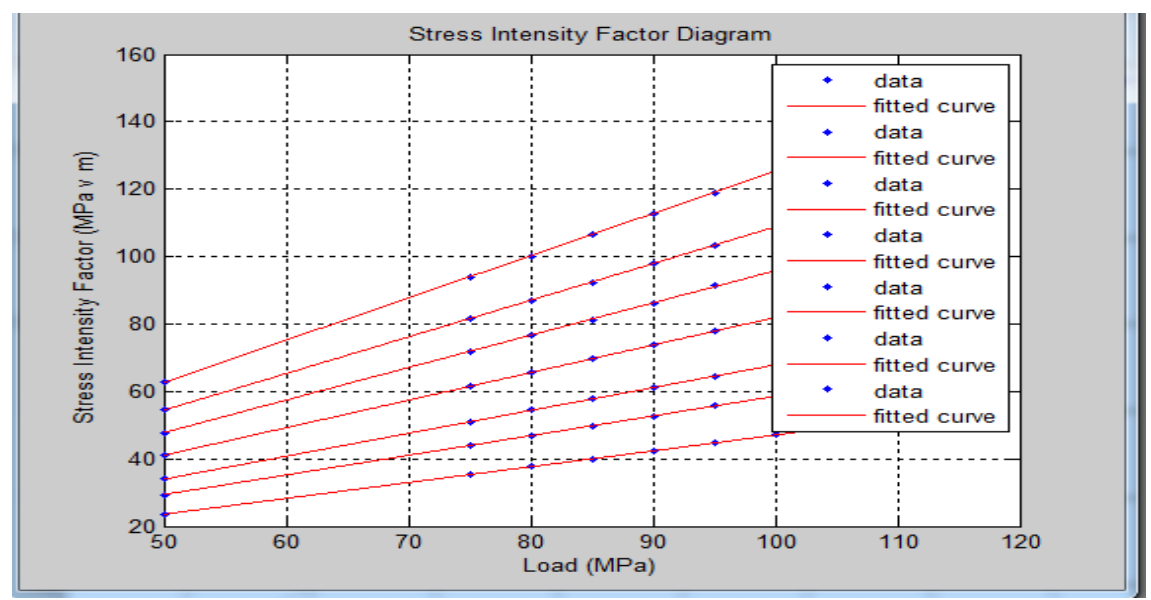

Figure 12. The curve fitting of Stress Intensity Factor 
The suitability coefficient $\mathrm{R}$ of J-Integral curve fitting equal to 0.95671 , shown in Figure 13 . This coefficient is close to 1 , so the modeling approach as expected.

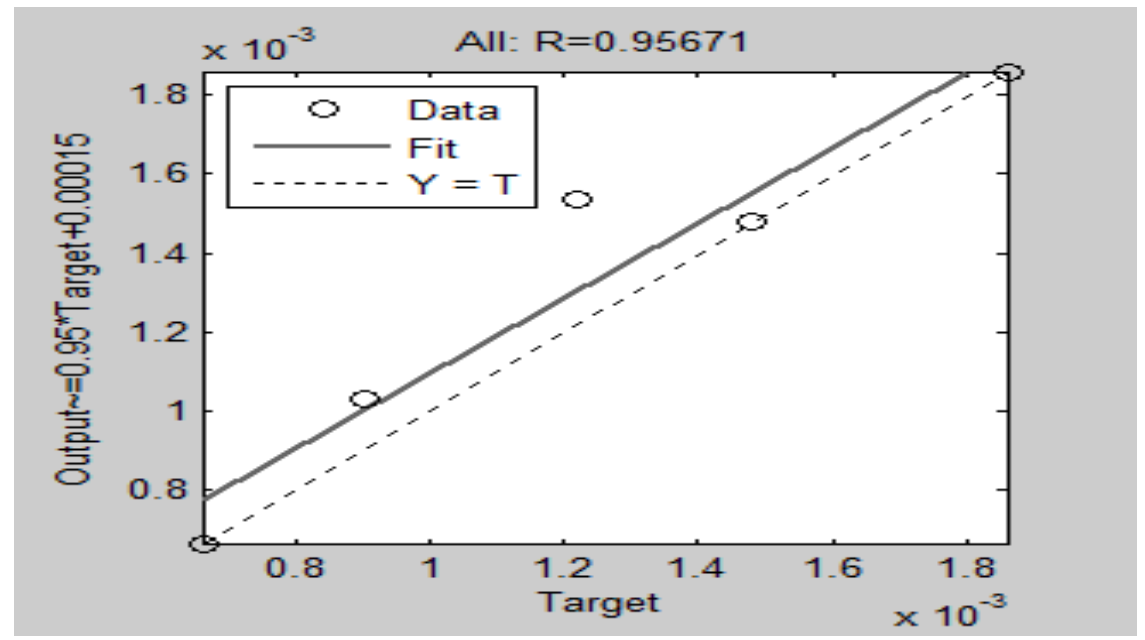

Figure 13. The coefficient $\mathrm{R}$ of the J-Integral.

The suitability coefficient of SIF model, R equal to 0.9287 shown in Figure 14. This coefficient is close to 1 , then the modeling approach is expected.

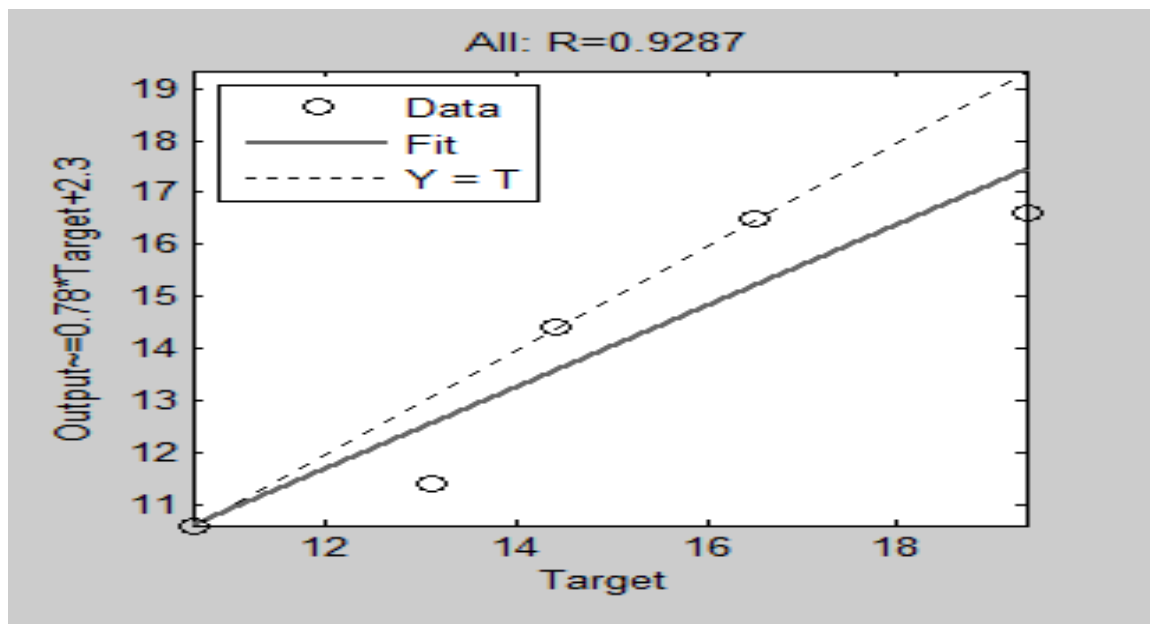

Figure 14. The coefficient $\mathrm{R}$ of the SIF

The fitting function of the J-Integral modeling based on a neural network in Figure 10 is given in Tabel 4. The fit function is the estimation curve J-Integral for initial crack position a given respectively by $50,75,100,125,150,175$ and $200 \mathrm{~mm}($ Fit1(x), Fit2(x), ...., Fit7(x)) from the edge of the plate with a load variation 50 to $115 \mathrm{MPa}$. This model is a polynomial function degree two, Fit $(x)=p 1 x 2+p 2 x+p$ with the equation coefficients each $\mathrm{p} 1, \mathrm{p} 2, \mathrm{p} 3$ and standard deviation with $95 \%$ confidence limit.

The modeling of the SIF based on a neural network in Figure 12 is given in Tabel 5. The estimation curve SIF for an initial crack position is a polynomial function degree two with the coefficients equation each p1, p2, p3 and standard deviation with $95 \%$ confidence limit. Those are given respectively by $50,75,100,125,150,175$ and $200 \mathrm{~mm}$ from the edge of the plate with a load 50 to $115 \mathrm{MPa}$. 
Table 4. The modeling results for J-Integral

\begin{tabular}{ccccc}
\hline Fitness Function & $p 1$ & $p 2$ & $p 3$ & $\begin{array}{c}\text { Standard Deviation } \\
\left(x 10^{-5}\right)\end{array}$ \\
Fit(x) & $\left(x 10^{-6}\right)$ & $\left(x 10^{-6}\right)$ & & 2.37 \\
\hline Fit1(x) & 1.05 & 3.65 & -0.00011 & \\
Fit2(x) & $(1.00 ; 1.102)$ & $(-4.85 ; 1.21)$ & $(-0.00046 ; 0.00024)$ & 6.33 \\
& 1.66 & 1.79 & -0.000054 & \\
Fit3(x) & $(1.53 ; 1.79)$ & $(-2.08 ; 2.45)$ & $(-0.00098 ; 0.00024)$ & 2.25 \\
Fit4(x) & 2.20 & 5.83 & -0.00020 & 2.66 \\
Fit(5x) & $(2.15 ; 2.25)$ & $(-2.22 ; 13.9)$ & $(-0.00053 ; 0.00013)$ & 1.84 \\
Fit6(x) & 3.27 & -0.85 & 0.000079 & \\
& $(3.21 ; 3.32)$ & $(-104 ; 0.87)$ & $(-0.00032 ; 0.00048)$ & 7.75 \\
Fit7(x) & 4.33 & 21.95 & -0.00085 & \\
& $(3.94 ; 4.72)$ & $(-43.9 ; 87.83)$ & $(-0.0036 ; 0.0018)$ & 5.30 \\
\hline
\end{tabular}

Table 5. The modeling result for Stress Intensity Factor

\begin{tabular}{ccccc}
\hline Fitness Function & $p 1$ & $p 2$ & $p 3$ & Standard Deviation \\
Fit(x) & $\left(x 10^{-5}\right)$ & $\left(x 10^{-6}\right)$ & & $\left(x 10^{-5}\right)$ \\
\hline Fit1(x) & 1.523 & 0.4673 & 0.15 & 0.0049 \\
& $(0.4889 ; 2.556)$ & $(0.4655 ; 0.4690)$ & $(0.07 ; 0.22)$ & 0.0090 \\
Fit2(x) & 5.127 & 0.5758 & 0.46 & \\
& $(3.217 ; 7.036)$ & $(0.5725 ; 0.579)$ & $(0.33 ; 0.59)$ & 0.0397 \\
Fit3(x) & -5.965 & 0.6878 & -0.3192 & 0.0085 \\
Fit4(x) & $(-14.41 ; 2.47)$ & $(0.6735 ; 0.702)$ & $(-0.903 ; 0.26)$ & \\
& 4.023 & 0.8115 & 0.361 & 0.2055 \\
Fit(5x) & $(2.214 ; 5.832)$ & $(0.8084 ; 0.8145)$ & $(0.2357 ; 0.4863)$ & 0.0914 \\
Fit6(x) & 15.73 & 0.9844 & -1.102 & \\
Fit7(x) & $(-59.35 ; 27.01)$ & $(0.9108 ; 1.058)$ & $(-4.12 ; 1.92)$ & 1.077 \\
& 6.96 & 0.35 & $(1.045 ; 1.11)$ & 0.0446 \\
\hline
\end{tabular}

The range of the load for material SA 508 on the wall of the pressure vessel can determine using the result of the J-Integral and the SIF. The range maximum of the material resistance caused by the influence the load can be evaluated at the position of the initial crack. From Table 3 and based on fracture toughness for SA 508, the load is allowable in range 25 until $100 \mathrm{MPa} \sqrt{m}$ with the position of the initial crack 50 until $150 \mathrm{~mm}$. The trend of stress intensity factor and J-integral has been modeled for some load on the position of initial crack using a neural network approach. The curve fitting is a polynomial of degree two. This curve is very close to a plot of some input data.

\section{CONCLUSION}

The analysis of mechanical fracture has been performed on a material resistance of SA 508 which is commonly used in the wall of PWR pressure vessel. This evaluation uses the calculation of J-integral and Stress Intensity Factor. The result of Stress Intensity Factor compares with the 
value of fracture toughness which is recommended for material SA 508 which use in the wall of PWR pressure vessel. This results can be used to determine a range of the load which can be given so that the occurrence of fracture due to cracks can be evaded. For the initial crack in range $50 \mathrm{~mm}$ until $150 \mathrm{~mm}$, the load are allowable in range 25 until $100 \mathrm{MPa} \sqrt{\mathrm{m}}$. The modeling of the Jintegral and Stress Intensity Factor has been obtained based on neural network. Through the modeling for the load which given, the resistance of material can be known through the position of surface cracks. The fitting curve is a polynomial degree 2 with small standard deviation. This model can use to prediction the Stress Intensity Factor for some load.

\section{ACKNOWLEDGMENT}

The authors are grateful for the financial support from DIPA-BATAN. We also thank Ir. D.T. Sony Tjahyani M. Eng. as a coordinator in this research and Ir. Surip Widodo M. IT. as responsible of KAK.

\section{REFERENCES}

1. Gopichand A., Srinivas Y., Sharma A. V. N. L., Computation of stress intensity factor of brass plate with edge crack using the J-Integral technique. International Journal of Research in Engineering and Technology 2012; 01:261-266

2. Yamashita Y., Hirano T., Scatter band prediction for fracture toughness of specimens with the prior load. Engineering Fracture Mechanics 2012; 86:73-89

3. Han Q., Wang Y., Yin Y., Wang D., Determination of stress intensity factor for mode I fatigue crack based on finite element analysis. Engineering Fracture Mechanics 2015; 138:118-126

4. Li Y., Itoh H., Osakabe K., Onizawa K., Yoshimura S., Benchmark analysis and numerical investigation on probabilistic fracture mechanics analysis codes for NPPs piping. International Journal of Pressure Vessels and Piping 2012; 99-100:61-68

5. Li Shuxiao, Zhang H., Li Shiley, Wang Y., Xue F., Wang X., Probabilistic fracture mechanic analysis of thermally aged nuclear piping in pressurized water reactor. Nuclear Engineering \& Design 2013; 265:611-618

6. Chen B., Huang C.C., Chou H.W., Lin H.C., Liu R.F., Weng T.L., Chang H.J., Reactor pressure vessel integrity assessment by probabilistic fracture mechanics a plant-specific analysis. International Journal of Pressure Vessels and Piping 2014; 117-118:64-69

7. Kempf R., Troiani H., Maria Fortis A., Effect of lead factors on the embrittlement of RPV SA-508 cl 3 Steel. Journal of Nuclear Materials 2013; 434:411-416

8. Kim S.H., Kim S.Y., Shen T., Park K.T., Kim I.H., Koo J.M., Seok C.S., Fracture Toughness of SA 508 GR. 1A Nuclear Piping Using Compact Tension (CT) and Large Curved CT specimen. International Journal of Advances in Science and Technology 2014; p.142-146

9. Lu M., Yu J., Chen J., The effect of analysis model on the stress intensity calculation for the nozzle attached to pressure vessel under internal pressure loading. International Journal of Pressure Vessels and Piping 2014; 117-118:9-16

10. Wu Z, Hu S., Zhou F., Prediction of stress intensity factors in pavement cracking with neural networks based on semi-analytical FEA. Expert Systems with Applications 2014; 41:1021-1030

11. Zerbst U., Klinger C., Clegg R., Fracture mechanics as a tool for failure analysis : prospect and limitation. Engineering Failure Analysis. 2015; 55:376-410

12. Wang H, Lei J., Yang Q., J-integral Calculation of Nonlinear Fracture for Colloidal Soft Material, 13th International Conference on Fracture; 2013 June 16-21. Beijing China 
13. Lee K., Jo M., Jo J.M., Kim M., Lee B., Effects of Tempering and PWHT on Microstructures and mechanical properties of SA508 GR.4N Steel. Nuclear Engineering and Technology 2014; 46:413-422

14. AP 1000 European design control document, EPS GW GL 700 Revision 1, Westing House Electric company 2009 